\title{
Chapter 10 \\ PATENT SEARCH IN STRATEGIC DECISIONS MAKING OF COMPANY
}

\section{Makhova H. V., Vostriakova V. Y., Vostriakov O. V.}

\section{INTRODUCTION}

Modern companies act in specific conditions that create new requirements for their efficient function. Powerful manufacturing facilities or raw material advantages have long been insufficient to provide competitive advantages. Intangible assets of the company, such as trademarks, patents, goodwill, and know-how become more and more important. Character of intangible assets differs significantly in different industries such as their influence on business models of companies. But share of intangible assets in forming of companies' income achieves $30-40 \%$. For example, in area of food, beverages and tobacco product income share of intangible assets is $31 \%$, in petroleum products $42.1 \%$, pharmaceutical products $-34.7 \%$, printing products $-27.1 \%{ }^{1}$

Intangible assets not only affect company's income, its value, level of its competitiveness and stability, but they are objects of analysis for making strategic decisions. Objects of intellectual property are key factors of acceptation or rejection of decision about expediency of investment in research and development, feasibility of developing a new product and its launch, entering the new geographic market, merger and acquisition, forming strategic partnership, etc. Issues of intellectual property are especially important and cannot be ignored by company when it is entering the international market. The role of the intellectual property has been recognized as important part of institutional infrastructure for stimulation of investment in research and development, in particular in the industrial and scientific areas.

Patents have a special place in the list of objects of intellectual property; accordingly, patent search should become one of the tools for analysis of activity's directions and development of strategic decisions of the company. Patents are exhaustive source of technical and business information. It is essential to analyze level of technological development

\footnotetext{
${ }^{1}$ Chen, W., R. Gouma, B. Los and M. Timmer (2017). Measuring the Income to Intangibles in Goods Production: A Global Value Chain Approach. WIPO Economic Research Working Paper No. 36. Geneva: WIPO.
} 
in specific area for avoiding wasting time and money on something that already exist.

According to WIPO information European industry loses 20 billion dollars every year due lack of patent information's use. Companies make efforts and try re-solve problems that have already been solved, spent money and time to launch products, that are on the market ${ }^{2}$. Instead of this patent information should be used in context of developing and marketing of new products, monitoring of market trends, analysis of competitors' activity and making strategic decisions.

\subsection{Essence of invention's patenting}

The role of patents in global economy, economies of countries and companies' economy has significantly increased over last years. Globalization of economy, convergence of industries, distribution and active use of digital technologies play great role in the process of intellectual property's development. More and more countries are involved in the global process of intellectual products' creation. It determines issues of management and protection of intellectual property.

It's confirmed by positive dynamics of patent application all over the world (Figure 1).

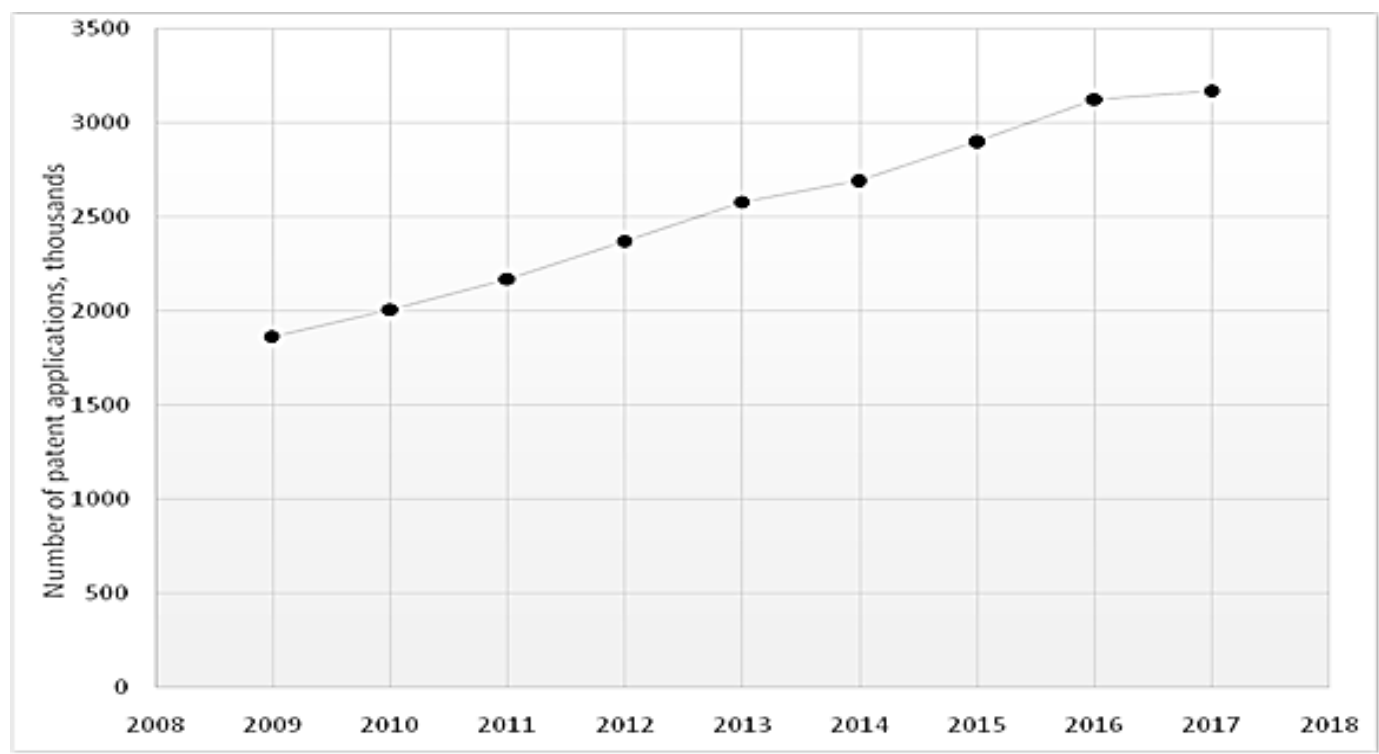

Figure 1. Dynamics of patent applicationin the world, 2009-2017, applications ${ }^{3}$

\footnotetext{
${ }^{2}$ WIPO (2017). World Intellectual Property Report 2017 - Intangible Capital in Global Value Chains. Retrieved from: https://www.wipo.int/publications/en/details.jsp?id=4225\&plang=en

WIPO (2019)WorldIntellectualPropertyIndicators 2018.Retrieved from:https://www.wipo.int/edocs/ pubdocs/en/wipo_pub_941_2018.pdf.
} 
In structure of intellectual property filing activity patents had share 15,8\% in 2018 (Figure 2).

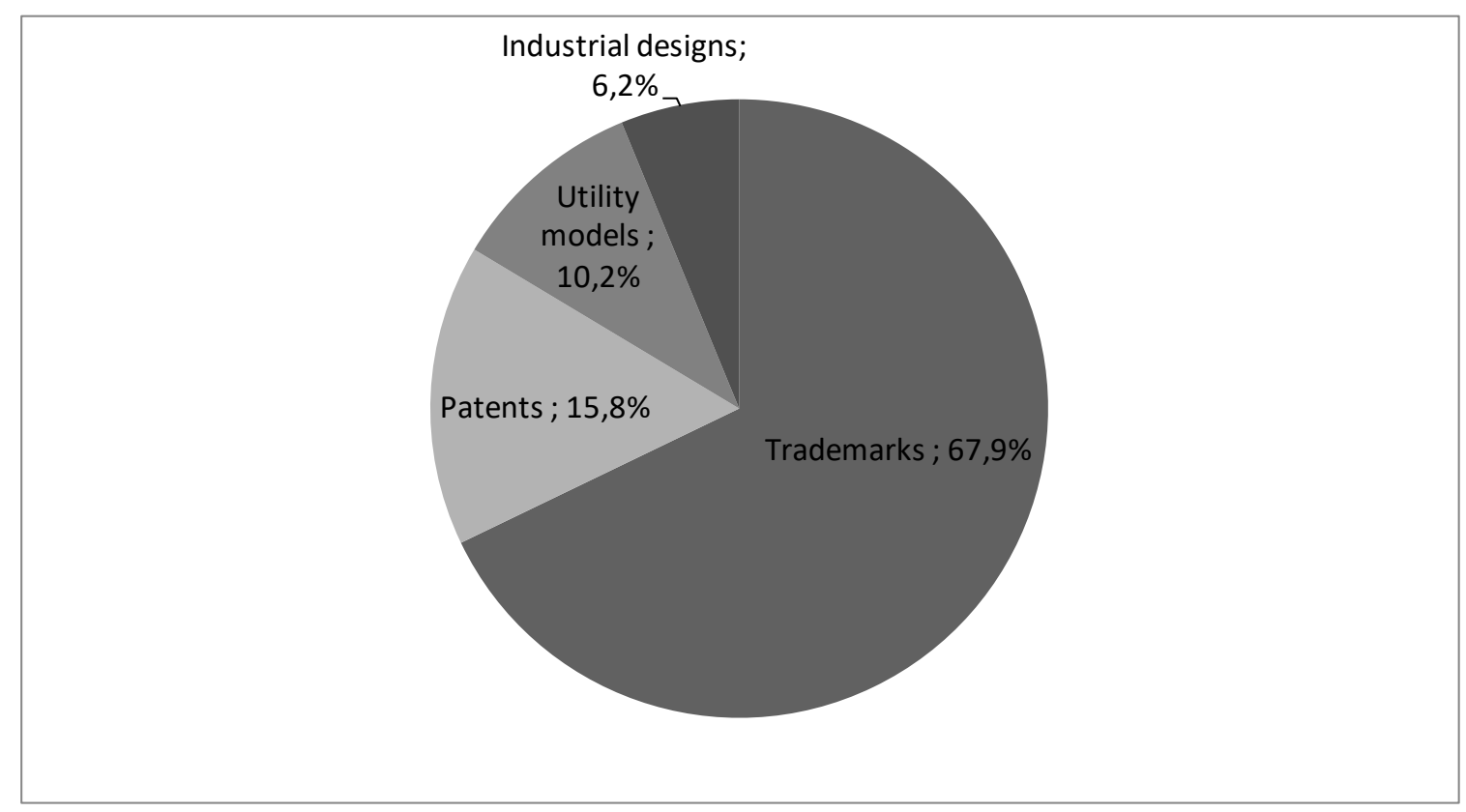

Figure 2. Structure of IP filing activity ${ }^{4}$

Structure of patent filing by region is shown in Figure 3.

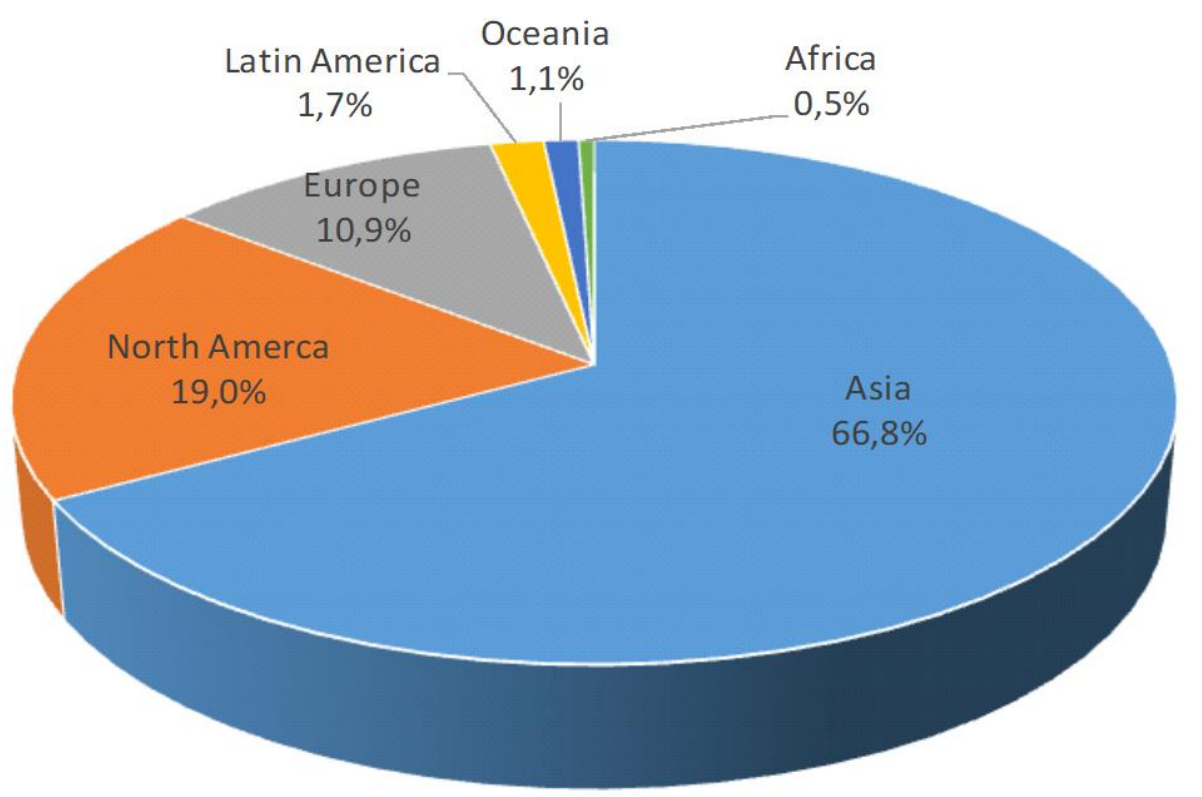

Figure 3. Structure of patent filing by region ${ }^{4}$

WIPO (2019) Facts and Figures. Retrieved from:https://www.wipo.int/edocs/infogdocs/ en/ipfactsandfigures2018/ 
Table 1 shows structure of published patents applications by fields of technology in 2017.

Table 1

Published patents applications by fields of technology, $2017^{5}$

\begin{tabular}{|c|c|c|}
\hline Field of technology & $\begin{array}{c}\text { Number of published } \\
\text { applications }\end{array}$ & Share of total, \% \\
\hline Electrical engineering & 866903 & 29.4 \\
\hline Instruments & 439984 & 14.9 \\
\hline Chemistry & 723945 & 24.5 \\
\hline Mechanical engineering & 655144 & 22.2 \\
\hline Other fields & 264629 & 9.0 \\
\hline Total & 2950605 & 100 \\
\hline
\end{tabular}

The most successful businesses in the world are based on the innovative ideas, which are non-physical resources. There are different motives to create new ideas, products, process and technologies, such as recognition and acknowledgment, satisfaction from results of intellectual activity and research and so on. But often it is not enough to encourage researchers to invest their resources in new inventions. In these aspects, intellectual property is part of innovation system and allows inventors to restrict the use of their knowledge, obtain a return on their investment ${ }^{6,7}$

Patent system is aimed at innovations' enforcement and stimulation of economic growth by:

- protecting of creativity's results and insolvent of investment in development of new invention;

- publication and disclosure of technical information about new inventions.

There are two main functions of patent system:

- legal protection of intellectual property, which has territorial character, i.e. protection is limited by country or region;

- disclosure of patent information that is carried out globally, so any person can get this information.

\footnotetext{
${ }^{5}$ WIPO (2019) World Intellectual Property Indicators 2019. Retrieved from: https://www.wipo.int/ edocs/pubdocs/en/wipo_pub_941_2019.pdf?fbclid=IwAR1YRRP_TRTt4FHoOy2e2Z5zrewvobV0eBGlP8nbirZIezQK7shrlN4-vk

${ }^{6}$ Maximiliano Santa Cruz S., PilarTrivelli (January 2016). Interaction between Intellectual Property and Competition Laws. E15Initiative. Retrieved from: http://e15initiative.org/publications/interaction-betweenintellectual-property-and-competition-laws/

7 Stiglitz, Joseph E. (2008). Economic Foundations of Intellectual Property Rights. Duke Law Journal, Vol. 57. Retrieved from: https://scholarship.law.duke.edu/cgi/viewcontent.cgi?article=1362\&context=dlj
} 
There are a lot of data bases that provide free access to patent information. Each of them covers specific compilation of patent documents. None of them covers all patent documentation published in the world. But they all provide follows:

- Title - depicts the essence of the invention;

- Abstract - gives a brief summary of the invention, forms main idea of the document's content;

- Description, drawings, claims - facilitate the extraction of information. Claims define the scope of novelty, description gives background of the invention (the "prior art") and describes difference between existing technology and given invention. Drawings illustrate the invention. Technological information describe the invention according to requirements of patent law;

- Patent/ Publication/ Application/ Priority number(s) - documents have various identification number and codes on different resources, but these numbers give opportunity to make search fast and easy;

- Dates - date of application, priority date, date of grant;

- Classifications -"classification symbols" facilitate the finding and extracting of relevant information. There are several classification system, but International Patent Classification (IPC) is widely applied.

- Inventor, Applicant, Owner - sometimes the inventor is the applicant. Information contains legal address of owner or applicant;

- Citations - can be patent or non-patent documents.

- Examiner/ Attorney;

- Country Information - information about country of filing helps to identify the jurisdiction of patent;

- Patent Family - shows patents filed in more than one country.

The reason to use different data bases is to find patent documentation and get access to needed patent documents. Electronic data bases, software help to analyze patent information quit fast and full.

Patent provides exclusive rights to its owner, in particular to limit commercial and other exploitation of invention by thirds persons. Due to these exclusive rights patent's owner can get temporary monopoly of invention's use. It provides enhancement of company's market positions, redounds increasing of revenue through royalty and contributes positive image of the company. Patents are those tools that help to turn innovative idea or invention into competitive product which provides increasing of profit, so patents help to commercialize inventions. 
Main reasons of inventions' patenting are following:

- Exclusive rights to prevent others from commercial using of the invention, so called negative rights, that are valid for twenty years from the patent application;

- Opportunity of invention's commercialization provides to patent's owner higher returns on investment;

- Exclusive rights provide stronger market positions for patent's owner;

- Opportunity to license or sell the invention if company doesn't want to exploit the patented invention by itself. Selling of invention is a source of company's revenue;

- Positive image of company - set of patents illustrates level of company's technological development and expertise and can increase attractiveness of company for potential investors and partners.

W. M. Cohen, R. R. Nelson, and J. P. Walsh researched main reasons to patent innovations by responded more than 600 manufacturers. According to this research principal motive is to prevent copying (Table 2).

Table 2

Reasons to patent innovations ${ }^{8}$

\begin{tabular}{|l|c|c|}
\hline \multirow{2}{*}{\multicolumn{1}{|c|}{ Reasons }} & \multicolumn{2}{c|}{ Type of innovation } \\
\cline { 2 - 3 } & Product Innovation, \% & Process Innovation, \% \\
\hline To prevent copying & 95 & 77 \\
\hline For licensing revenue & 28 & 23 \\
\hline To prevent law suits & 59 & 47 \\
\hline To block others & 82 & 64 \\
\hline For use in negotiations & 47 & 43 \\
\hline To enhance reputation & 48 & 34 \\
\hline To measure performance & 6 & 5 \\
\hline
\end{tabular}

As mentioned above patents help to commercialize invention. According to GrantR.M. there are several ways to achieve this and maximize returns to innovation ${ }^{9}$ :

\footnotetext{
${ }^{8}$ Cohen W. M., Nelson R. R., Walsh J. P. (February 2000) Protecting their Intellectual Assets: Appropriability Conditions and Why us Manufacturing Firms Patent (Or Not). NBER Working Paper No. W7552. Retrieved from: https://www.nber.org/papers/w7552.pdf
} 
- Licensing;

- Outsourcing certain functions;

- Strategic alliance;

- Joint venture;

- Internal commercialization (Table 3).

Table 3

Alternative strategies for exploiting innovation

\begin{tabular}{|c|c|c|c|c|c|}
\hline & Licensing & $\begin{array}{l}\text { Outsourcing } \\
\text { certain } \\
\text { functions }\end{array}$ & $\begin{array}{l}\text { Strategic } \\
\text { alliance }\end{array}$ & Joint venture & $\begin{array}{c}\text { Internal } \\
\text { commercia- } \\
\text { lization }\end{array}$ \\
\hline 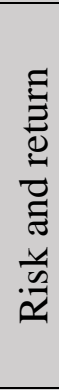 & $\begin{array}{l}\text { Little investment } \\
\text { risk but returns } \\
\text { also limited. } \\
\text { Risk that the } \\
\text { licensee either } \\
\text { lacks motivation } \\
\text { or steals the } \\
\text { innovation }\end{array}$ & $\begin{array}{l}\text { Limits capital } \\
\text { investment, but } \\
\text { may create } \\
\text { dependence on } \\
\text { suppliers/ } \\
\text { partner }\end{array}$ & $\begin{array}{c}\text { Benefits of } \\
\text { flexibility. } \\
\text { Risks of } \\
\text { informal } \\
\text { structure }\end{array}$ & $\begin{array}{c}\text { Shares } \\
\text { investment and } \\
\text { risk. } \\
\text { Risk of partner } \\
\text { disagreement } \\
\text { and culture } \\
\text { clash }\end{array}$ & $\begin{array}{l}\text { Biggest } \\
\text { investment } \\
\text { requirement and } \\
\text { corresponding } \\
\text { risks. } \\
\text { Benefits of } \\
\text { control }\end{array}$ \\
\hline 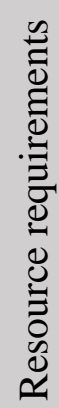 & Few & $\begin{array}{c}\text { Permits } \\
\text { external } \\
\text { resources and } \\
\text { capabilities to } \\
\text { be accessed }\end{array}$ & $\begin{array}{r}\text { Permits } \\
\text { resources at } \\
\text { more tl }\end{array}$ & $\begin{array}{l}\text { ooling of the } \\
\text { d capabilities of } \\
\text { an one firm }\end{array}$ & $\begin{array}{l}\text { Substantial } \\
\text { requirements in } \\
\text { terms of finance, } \\
\text { production } \\
\text { capability, } \\
\text { marketing } \\
\text { capability, } \\
\text { distribution, etc. }\end{array}$ \\
\hline
\end{tabular}

Making decision about strategic partnership or joint venture, company should thoroughly analyze potential partners, their activity and capabilities. And patent search can provide wide range of appropriate information.

\subsection{Directions of patent search}

Patents provide corporations and individuals both technical and strategic information. This strategic information may be even more effective than technical content. Such information can be used to making decisions about start of $\mathrm{R} \& \mathrm{D}$, launch new products, enter new

\footnotetext{
${ }^{9}$ Grant R.M. (2016) Contemporary Strategy Analysis: Text and Cases Edition 9th ed. Wiley.
} 
geographical market, merger and acquisition, forming strategic partnerships. Information that can be used for a particular decision is discussed below.

To make decision about expediency of $R \& D$ conducting, one should provide state-of-the art search that is carried out to review the level of development in a particular technical area. Main goal of this search is to avoid spending of money, efforts and time for some inventions that are already existed. Also it may be found out what solutions exist in some technical sphere, specificity of their development and their patent protection - are patents valid? What is patent family? How can be novelty reached? What are technology trends on the market and what are main directions of R\&D of competitors?

For these goals, such patent information may be used:

- Invention's description - clear and concise explanation of existing technologies, that are relevant to new invention, and how this invention may be used to solve technical issues, which are not solved by existing technologies;

- Claims - the legal definition of the technical essence of the invention for which application is filed; claims describe invention and its technical characteristics;

- Name of inventor and applicant;

- Date of application;

- Legal status of patent;

- Patent family.

Patent information can be described as:

- Technical information - from description and drawings of the invention;

- Legal information - from the patent claims;

- Business-relevant information - from reference data about inventors, date of filing, owner, country of origin, etc;

- Public policy-relevant information - from analysis of filing trends to be used by policymakers (national industrial policy strategy) $)^{10}$.

There is opportunity to analyze technical and market activity of competitors by observing their filed applications and granted patents. Market technology trends and companies' directions of R\&D can be

\footnotetext{
${ }^{10}$ WIPO (2015) WIPO Guide to Using patent information. Retrieved from: https://www.wipo.int/ edocs/pubdocs/en/wipo_pub_1434_3.pdf
} 
gleaned. Also one can analyze life cycle of technology and find out timing of research and development process.

Knowing which companies or individuals are technological leaders in your area of business can play an important role in planning commercial, research and development activities of company. Patenting activity and patent ownership can be important in identifying principal innovators in different areas of technology ${ }^{10}$.

Analysis of patent applications, their dynamics and spheres can be used by politicians for designing of national strategy of industry's development. Patent documentation gives statistic data about level of patent activity in different countries and regions.

Patent search can demonstrate inventors who are most important for the company and its research activity. It may be key information for decision about merger and acquisition. Analysis of inventors of competitive companies can be useful for headhunting. Name of inventors is important information for company that wants to hire talent employee to enforce competitive position on the market. Name searches give information about technological areas, where competitors act.

Also it can be found out in which countries competitors apply for patent and according to this information it can be assumed where they would like sell their products.

It is important to know in which countries patents are granted, especially making decision about entering new international market. As patent provide to its owner right to prevent other persons making, using offering to sell, selling or importing inventions, valid patents should be analyzed to avoid infringements.

Firstly, company should check patents of competitors in those countries where it wants to carry out activity. Next step is to check validity of these patents, i.e. analyze legal status of relevant patents or patent application in specific countries or regions. There is annual renewal fee which are required by some authorities and provides validity of granted patent. In case of pay's failure patent will be lapsed. Patent may be amended after grant by owner or it may be annulled by the court.

If patent is in force, it should be check is invention new and not obvious. If invention does not appear to be new, company may get the court decision about withdrawing or get better terms for licensing.

Patent search should cover patent information about applications filed on PCT system, national and regional applications. 
As patent is valid in country company wants to enter and plans market its product, it should analyze and evaluate existing applications and petitions about this invention. Company can avoid infringement through modifications of its product according to patent information. It should be taken into account that application is published in 18 months after filing date. So, it is important to monitor patent information in technological spheres of company's product. Different searching services combine notifications' tools, in particular RSS channels that make this process easier. RSS-channel provides newest information about international applications that are relevant to particular businessinterests. Content of channel updates constantly with publication of new applications.

Analyze of legal status of patents or patent applications and other equivalent documents helps find out legal standing of invention in country or region.

When company is negotiating a patent license or planning to form partnership or merge other company analysis of patents' validity helps to evaluate asset base and analyze strength and value of patents. References in patent documents - to other patents, applications and cited information in national and international reports - could be useful in evaluation of particular patents. For example, frequent references to patent in later patent documents indicate technical relevance and its value.

Ignoring of patent search to discover if there are any valid patents in country or region can lead to infringement and as result to expensive court actions or even award of damages. Also it influences negative at company's reputation and value.

So, legal status information assists to make decision about market entering in particular country or region, assessing the validity of patents and their value, in the license agreement's negotiations and avoid infringement and court action.

Monitoring of patent information is useful not only in case of entering new market, but for protection of company's own market and identification of potentially dangerous competitors. Patent provides to its owner temporary monopoly and in this way gives to him some competitive advantages. But patent's owner cannot ignore developments of other companies, modifications of products and scientific and technological progress. Companies, on the one hand, can prevent illegal use of their inventions, and on the other hand can explore directions of development of technologies/products, possibility 
of appearance of new competitors and on this basis make decisions about own research, investment and other actions, which will provide competitive positions. So, patent search gives information about new potential market and define trends and perspectives of existing market. Main actions for protection of competitive positions by using patents are shown in Figure 4.

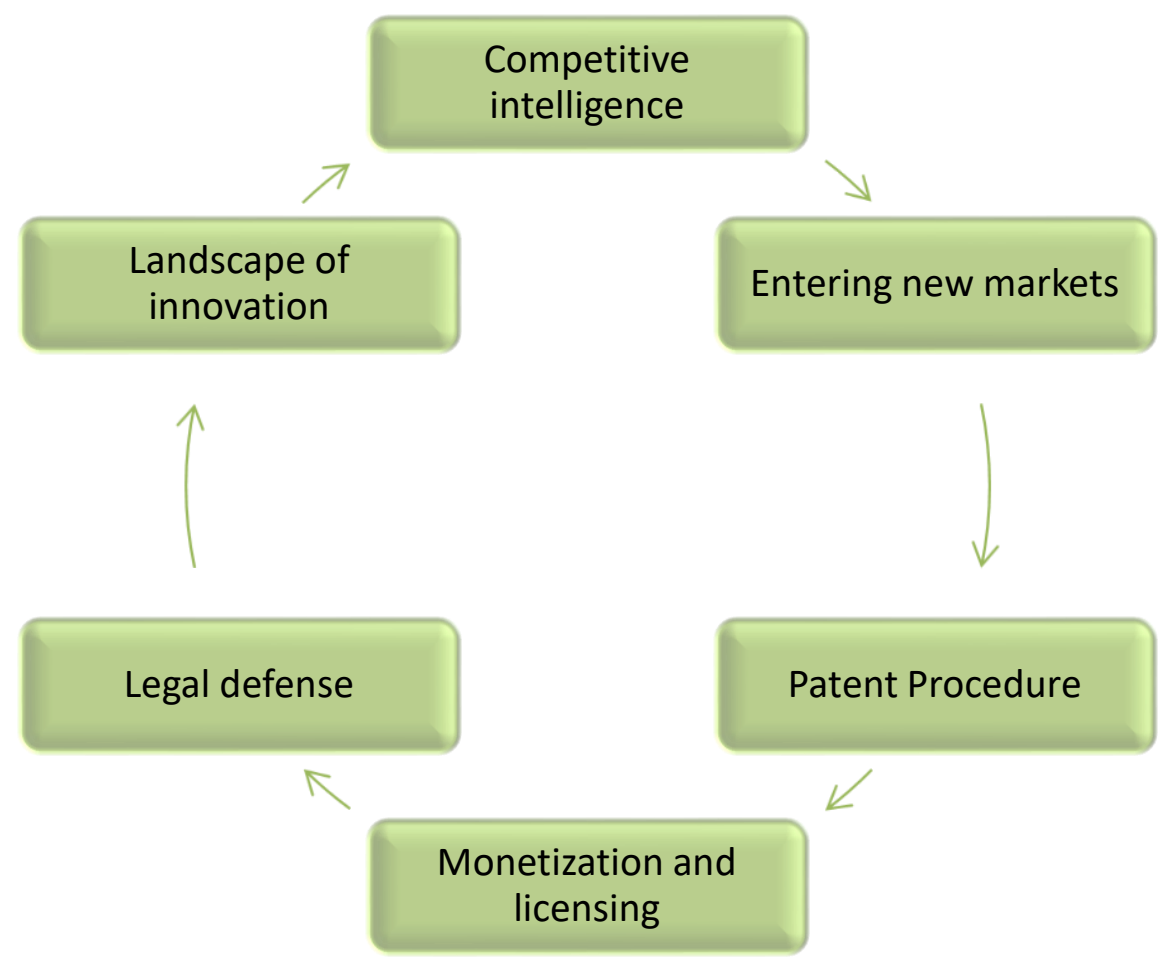

\section{Figure 4. Actions for protection of company's market positions by using patents ${ }^{11}$}

A patent's most direct use is the ability to obtain an injunction against infringement by a competitor who makes, uses, sells, offers to sell or imports a product or service covered by the patent's claims. Under certain circumstances, this "blocking patent" gives its owner control of the industry or product line related to that patent ${ }^{11}$.

Moreover, patent is a powerful marketing tool. Patented product is more credible for consumers than similar product without patent

11 Derwent Innovation (2017) Poiskianalitika svedeniy o relevantnykh patentakh dlya prinyatiya obosnovannykh resheniy $v$ otnoshenii intellektual'noy sobstvennosti I biznesa [Search and analytics of relevant patent information for making informed decisions regarding intellectual property and business] Retrieved from: https://clarivate.ru/wp-content/uploads/2018/07/clarivate_analytics_derwent_innovations_ brochure.pdf(in Russian) 
protection. Clients, in particular, retailers and state customers, prefer suppliers who have protected rights of intellectual property ${ }^{12}$.

Companies routinely refer to their "patented technology" in press releases and advertising materials. Some companies even provide information about their patent portfolios in their investment materials ${ }^{13}$.

Next important way to use patent information is prospecting for potential strategic partnerships or licensing opportunities. Important issues of forming strategic partnership are to find appropriate partners with particular assets, technologies and strategic goals. Problem of search and analysis of potential partner is key problem of effective functioning of partnership. Wrong choice of partner leads to conflicts and non-efficient activity of all partners. Patent search gives opportunity to analyze patent families of potential partners, their research directions, granted patents and their values and find companies that are complementary to company's business. Also it can be useful for investors who are looking for objects of investment, so they can analyze level of technological development of the companies, research activity, their respect of intellectual property rights and their perspectives in technological and marketing activity.

Patent search is a good way of identifying other businesses engaged in a particular field - if the searching company is looking to "license in" or "license out". For "licensing in" (a technology belonging to someone else that the searching company wishes to distribute or improve) or "licensing out" (a technology the searching company has developed but perhaps does not have the resources to commercialize) or "crosslicensing" (between two patent owners) it is needed to have relevant information about technology - target or key - to make right decision. Analysis of patent information can give valuable and exhaustive technical and business information about companies and technologies, their strengths and weaknesses.

Before "license in" a technology such questions should be examined:

- is technology protected by patent or in public domain? If it is in public domain, what are the reasons? Because a patent was not applied for or was applied for but not granted; or patent was lapsed or invalidated;

\footnotetext{
${ }^{12}$ Patent Service "Start Patent" (2019) 5 prichinpatentovat' svoirazrabotkipryamoseychas [5 reasons to patent your designs right now] Retrieved from: https://www.start-patent.ru/5reasons-patenting (in Russian)

${ }_{13}$ WIPO (2007)WIPO Patent Drafting Manual. Retrievedfrom:https://www.wipo.int/edocs/pubdocs/en/ patents/867/wipo_pub_867.pdf
} 
- is there possibility of someone sues and company will recover damages? others?

- isn't technology undervalued or overvalued in comparison with

Patent search helps license in technology. For example, company can locate dormant technology that has not found a licensee or manufacturer to commercialize it. But important question is to found out why technology is not being used. Sometimes, license to a technology that is not being used can be great chance for business. Technology can be exploited in a different geographical markets, it could be modified or used for other goals.

To "license out" company should explore follows:

- who could be licensees?

- what is value of technology?

- is technology core in company's business?

- what obstacles can appear when "licensing out"?

Patent information as result of patent search provides great basis for making different strategic decisions of company. But other types of information - such called "non-patent" information cannot be ignored. Non-patent information or literature includes printed and non-printed matter that may be technical relevant for the patent-granting procedure ${ }^{14}$. Non-patent literature includes:

- articles published in scientific journals;

- public conferences;

- research announcements (companies, forums, blogs, universities);

- public disclosure platform (social media, YouTube, Pinterest, books, magazines, datasheets, blueprints);

- withdrawn patents;

- sales and marketing materials;

- news sites;

- user guides;

- technical manuals;

- standards publications;

- corporate social pages, press releases, etc. ${ }^{15,16}$

\footnotetext{
14 Espacenet. Patent search (2019).Non-patent literature (NPL). Retrieved from: https://worldwide.espacenet.com/help?locale=en_EP\&method=handleHelpTopic\&topic=npl\&fbclid=IwAR2 kd6j6c9ufBMH-7mYTYlvmVpPmk-F-vQdB5W2vNAsvHD8HRGsJIaKkCI0

${ }^{15}$ Legal Advantage LLC (2019).Importance of Non-Patent Literature in IP Search. Retrieved from: https://www.legaladvantage.net/blog/importance-of-non-patent-literature-in-ipsearch/?fbclid=IwAR0L5CmErXtMP4L9t9h-0TWAUa1NFjcD8Ew1eqURzqFPHtK1-1C695fXOGk
} 
Use of non-patent information gives such opportunities to company:

- improvement search of "prior art";

- identification of new strategic possibilities for company;

- analysis of key competitors;

- efficient strategy of patent search.

In many fields of technology, non-patent literature plays a central role in defining the prior art and is, therefore, indispensable for determining the patentability of any innovation. WIPO has established a list of periodicals that intellectual property offices must consult when carrying out international searches as part of the patenting process under the PCT system. This list, known commonly as the PCT Minimum Documentation.

To provide efficient patent search some factors should be taken into account. First of all, aim of search has to be identified. Aim defines directions of search, depth, width and complexity of research. Depending on the criteria according to which patent data can be broken down, it can, for instance, be used to track the growth and changes in patent activity over time, examine the distribution of patent applications in a country by residents compared to non-residents, or identify the technical areas in which a country is predominantly active in terms of patenting activity ${ }^{10}$.

Patent search can take long time to be performed, especially state-of -art search. Sometimes researcher should search information in different databases, internet search engines and other source of patent and nonpatent information. Patent bases use different system of search, different approaches for search queries' formulation, field codes, cover different countries. Issue of different languages creates additional difficulties for searchers. Provision of efficient search requires not only long time, but some specific skills and experience, knowledge in particular technological spheres. This is reason of appeal to professionals in patent search. Moreover, such professionals have access not only to free, but to paid aggregated databases. Use of paid aggregator and/or attraction of professional searchers for qualitative expertise require some costs. So, one should make decision about balanced use of money and time to get appropriate result.

16 IP. Com (2019). Why Non-Patent Literature is Important to Your IP Strategy. Retrieved from: https://ip.com/blog/non-patent-literature-important-ip-strategy/?fbclid=IwAR0XgOPi-

0Tgexw4oESn4cqIUREyKkgYOSoA0uNUCvlJhia1oQUN9cldL7Y 


\section{CONCLUSION}

Making strategic decisions of company requires deep and rigorous analysis of its internal and external environment. Analysis of internal environment needs identification of appropriate methods, methodical tools and so on. Diagnostics of external environment is more complicated due limited and diverse information. For justification of any strategic decision company should analyse great massive of information of different types related to market, competitors, legislative base, technological aspects, social, political and economic factors. One of the main problems is to get information about competitors, their activity, intentions and plans. In this case patent search can be useful and can provide needed information. Proper use of patent information provides extensive information about competitors, market and technological trends, directions of technologies' development, etc. A search carried out in patent documents makes it possible to find information on recent developments in a range of technical areas. Patent search today is not only way of analysis of technological information; it provides economical, marketing, legal data for strategic use and justification of company's decisions. Results of patent search illustrate trend of technological development of some industries or level of development of particular technologies, directions of technological vectors of different companies. Patent search gives information about "prior art", i.e. existing level of development of technologies is some specific area. It is possible to define vitality important inventors for the company, portfolio of company's patents and their value. Using patent search company can find partners for forming of strategic partnership or appropriate company for merger or acquisition according to characteristics of their technologies described in patents and patents applications. Also patent search gives information for company that wants to "license in" or "license out".

We can use patent information for analysis of potential international markets, companies, which have patents in these jurisdictions, their validity, expiration date, owners, and patent family and so on. Company should monitors patent information to provide protection of its own market and avoid competitive rivalry.

Patent search, especially for strategic use, cannot be full without use of non-patent literature, which includes different types of printed and non-printed information, for example, public conferences, publications, information from social medias and so on. 
It is critical to keep in mind the limitations of the data in which the search is being carried out. Performing of patent search needs to solve problem of balanced use of money, time, and skills for efficient results.

Importance of intangible assets, globalization of economy, shortening of technologies' life cycle and other factors lead to increasing meaning of intellectual property and its protection. It can be assumed that in future more and significant will be issues of effective management of intellectual property in general and, in particular, patents and patents family. So, the further direction of research can be defined as efficient patent strategy and management of patent families.

\section{SUMMARY}

Importance of inventions' patenting is defined based on the world's statistics in sphere of intellectual property. Main functions of patent systems and advantages of patent protection for its owner are described. The issues of possibility of patent search's use for making strategic decisions of the company are examined, in particular, entering new market, launch of new product, forming strategic partnership, conducting $\mathrm{R} \& \mathrm{D}$ and so on. Attention is paid to use of patent information for analysis of competitors and their activity, protection of own market. Main types of information that company can get as results of patent search are identified. Moreover sources of non-patent information are explored. Problems related to patent search are described; in particular, time and money limitations, skills and experience of searcher, access to paid databases.

\section{REFERENCES}

1. Chen, W., R. Gouma, B. Los and M. Timmer (2017). Measuring the Income to Intangibles in Goods Production: A Global Value Chain Approach. WIPO Economic Research Working Paper No. 36. Geneva: WIPO.

2. WIPO (2017). World Intellectual Property Report 2017 Intangible Capital in Global Value Chains. Retrieved from: https://www.wipo.int/publications/en/details.jsp?id=4225\&plang=en

3. WIPO (2019). World Intellectual Property Indicators 2018. Retrieved from: https://www.wipo.int/edocs/pubdocs/en/wipo_pub_ 941_2018.pdf.

4. WIPO (2019). Facts and Figures. Retrieved from: https://www.wipo.int/edocs/infogdocs/en/ipfactsandfigures2018/ 
5. WIPO (2019) World Intellectual Property Indicators 2019. Retrieved from: https://www.wipo.int/edocs/pubdocs/en/wipo_pub_ 941_2019.pdf?fbclid=IwAR1YRRP_TRTt4FHoOy2e2Z5zrewvobV0eB GlP8n-birZIezQK7shrlN4-vk

6. Maximiliano Santa Cruz S., Pilar Trivelli (January 2016). Interaction between Intellectual Property and Competition Laws. E15Initiative. Retrieved from: http://e15initiative.org/publications/ interaction-between-intellectual-property-and-competition-laws/

7. Stiglitz, Joseph E. (2008). Economic Foundations of Intellectual Property Rights. DukeLawJournal, Vol. 57. Retrieved from: https://scholarship.law.duke.edu/cgi/viewcontent.cgi?article=1362\&cont ext $=\mathrm{dlj}$

8. Cohen W. M., Nelson R. R., Walsh J. P. (February 2000). Protecting their Intellectual Assets: Appropriability Conditions and Why us Manufacturing Firms Patent (Or Not). NBER Working Paper No. W7552. Retrieved from: https://www.nber.org/papers/w7552.pdf

9. Grant R.M. (2016). Contemporary Strategy Analysis: Text and Cases Edition 9th ed. Wiley.

10. WIPO (2015). WIPO Guide to Using patent information. Retrieved from: https://www.wipo.int/edocs/pubdocs/en/wipo_pub_ 1434_3.pdf

11. Derwent Innovation (2017). Poisk $i$ analitika svedeniy o relevantnykh patentakh dlya prinyatiya obosnovazhnykh resheniy $v$ otnosheniii intellektual'noy sobstvennosti i biznesa [Search and analytics of relevant patent information for making informed decisions regarding intellectual property and business]. Retrieved from: https://clarivate.ru/ wp-content/uploads/2018/07/clarivate_analytics_derwent_innovations_ brochure.pdf [in Russian]

12. Patent Service "StartPatent" (2019). 5 prichin patentovat' svoi razrabotki pryamo seychas [5 reasons to patent your designs right now] Retrieved from: https://www.start-patent.ru/5reasons-patenting [in Russian]

13. WIPO (2007). WIPO Patent Drafting Manual. Retrieved from: https://www.wipo.int/edocs/pubdocs/en/patents/867/wipo_pub_867.pdf

14. Espacenet. Patent search (2019). Non-patent literature (NPL). Retrieved from: https://worldwide.espacenet.com/help?locale=en_EP \&method=handleHelpTopic \& topic=npl\&fbclid=IwAR2kd6j6c9ufBMH7mYTYlvmVpPmk-F-vQdB5W2vNAsvHD8HRGsJIaKkCI0 
15. Legal Advantage LLC (2019). Importance of Non-Patent Literature in IP Search. Retrieved from: https://www.legaladvantage.net/ blog/importance-of-non-patent-literature-in-ip-search/?fbclid=IwAR0L5 CmErXtMP4L9t9h0TWAUa1NFjcD8Ew1eqURzqFPHtK1-1C695fXOGk 16. IP. Com (2019). Why Non-Patent Literatureis Important to Your IP Strategy. Retrieved from: https://ip.com/blog/non-patent-literatureimportant-ip-strategy/?fbclid=IwAR0XgOPi-0Tgexw4oESn4cqIUREyK kgYOSoA0uNUCvlJhia1oQUN9cldL7Y

\section{Information about the authors: Makhova H. V.}

$\mathrm{PhD}$, Associate Professor, Business-Economics and Entrepreneurship Department, SHEE "Kyiv National Economy University named after Vadym Hetman", Ukraine ORCID: https://orcid.org/0000-0002-0298-5857

Vostriakova V. Y. $\mathrm{PhD}$, Associate Professor, Business-Economics and Entrepreneurship Department, SHEE "Kyiv National Economy University named after Vadym Hetman", Ukraine ORCID: https://orcid.org/0000-0001-8999-6323 Vostriakov O. V. $\mathrm{PhD}$, Associate Professor, Management Department, SHEE "Kyiv National Economy University named after Vadym Hetman", Ukraine ORCID: https://orcid.org/0000-0002-9030-6569 